\title{
Reactive and Proactive Coping Behaviors in Russian First-Year Students: Diagnostics and Development Opportunities
}

\author{
Anna A. Bekhter', Alexander V. Gagarin², Olesya A. Filatova1 \\ ${ }^{1}$ Pacific National University, \\ 68 Karla Marksa St, Khabarovsk, 680000, Russian Federation \\ ${ }^{2}$ Russian Presidential Academy of National Economy and Public Administration, \\ 82 Vernadskogo Ave, Moscow, 119571, Russian Federation
}

\begin{abstract}
The relevance of the study is determined by the role of the adaptation processes of first-year students to the university environment, which is the most important (preliminary) stage for: (a) their successful overcoming of various learning difficulties; (b) comfortable and constructive interaction with teachers and other students; and (c) search and application of adaptive behavior strategies due to new living conditions. The development of proactive coping is a key factor in the students' efficient learning activity because it represents a "platform" for their personal growth. The aim of the study is to determine the possibilities of diagnostics and development of reactive and proactive coping behavior in first-year students. The study involved 272 first-year students at Pacific National University (including 136 students of an experimental group who sought help from the University Psychology Center in 2019 and 136 first-year volunteer students as a control group). The following methods were used for diagnostics: Proactive Coping Inventory (PCI), adapted by E.P. Belinskaya et al., Ways of Coping Questionnaire by R. Lazarus, adapted by T.L. Kryukova et al., Hardiness Survey by Salvatore Maddi adapted by D.A. Leontyev and E.I. Rasskazova, Time Perspective Inventory (TPI) by Ph.Ge. Zimbardo, adapted by A. Syrtsova et al. and Reflexivity Diagnostics Method by A.V. Karpov. As a result, the first-year students showed low levels of developed reactive and proactive coping, high levels of social and emotional support as well as escape-avoidance, average levels of strategic planning and search for informational support, and a reduced level of reflective, predictive resource. It is shown that the search for social, emotional and informational support is the basis for constructing adaptive behavior strategies. It is confirmed that self-control and the category of the future are moderating for all types of proactive coping. The conducted cluster analysis made it possible to identify three profiles, which differ in the levels and content of reactive and proactive behavior (non-adaptive, reactive and active with a tendency to proactive). Repeated measurements show that individual and group forms of psychological intervention cause changes in the indicators of reactive-proactive coping behavior, which can be regarded as a positive dynamics in the development of behavior in students of the experimental group. Finally, a conclusion was formulated about the possibilities of using various forms of psychological support (individual counseling, trainings, and self-help groups) in optimizing the first-year students' proactive coping behavior.
\end{abstract}

Key words: proactive coping behavior, reactive coping behavior, personal resources, first-year students, psychological assistance, training 


\section{Introduction}

Adapting first-year students to university life is an important transitional stage in personal and further professional development for young people (former schoolchildren and future professionals). It is obvious that at this stage they will have to overcome many difficulties, which the majority of applicants do not think about when entering a higher educational institution. These include a new social group, relationships with different teachers, living in a dormitory, a new ("foreign") city, and different living conditions. Many years of pedagogical experience allow the authors of this article to assert that first-year students are often not prepared to overcome the above-listed and many other difficult and stressful situations that meet them "on the doorstep" of a higher educational institution. Successful yesterday's school students may be not only ill-adapted to a different structure and logic of educational activity but also highly susceptible to emerging difficulties when they find themselves in a situation of "cascading collapse" of a whole series of stressful events. And this often leads to their maladaptation, causing the development of borderline mental states and, as a result, decreased motivation for learning activity (Straud, McNaughton-Cassill, 2019).

Therefore, the question of coping with difficult and stressful situations among first-year students remains one of the most important. Maladaptation can become one of the main reasons in the formation of mental and somatic health problems in first-year students (Bekhter, Golovacheva, 2020). And the appeal of a large number of them for psychological help, in our opinion, is due to the fact that in the first year of training there are many such "stressors" and they act almost simultaneously (Kuftyak et al., 2020).

The authors of numerous modern studies emphasize that, for people who are generally focused on emotional coping with stress and emotional support as a way of coping, stress is amplified many times over. And in this case, we can observe students who emotionally react to different events (cry, confront, get angry), but this in no way leads to solving problems (Belinskaya et al., 2019; Bekhter, 2019; Kuftyak, 2019). Effective psychological support in this case can be strategically built taking into account the development of different types of coping in students - reactive-active-proactive (Slabinsky et al., 2019). And in conditions of manifestation of maladaptive states in an "unfamiliar" life (university) environment, the development of proactive coping is not only a necessary factor in effective preparation for a future profession, but, ultimately, it is a "platform" for the students' personal and professional development (Vaculikova, 2016; Sleczka et al, 2016; Vaculikova et al., 2019; Miao, Gan, 2019; Straud, McNaughtonCassill, 2019; Bekhter, 2019).

In general, a person's proactive behavior (known as "proactive coping”, "future-oriented coping") is understood as anticipating a stressor and an attempt to cope "in advance" with building a strategic trajectory of life events and accumulating appropriate psychological (subjective) resources (Starchenkova, 2009, 2012). The reactive forms of coping behavior (what is called the classic "coping behavior") include strategies focused on solving specific problems in the present and the past and with the goal of adaptation (minimizing the risks of a difficult situation, survival, coping with past difficulties, distancing, etc.). Most often, this refers to a shortterm reaction of an individual to a stressful event (Starchenkova, 2009). 
Proactive and reactive coping behaviors are considered within the framework of different approaches and corresponding models of different authors: the cognitive approach, in which these two types of behavior are regulated by cognitive processes that allow one either to reduce the actions of the stressor (in the case of reactive coping) or to anticipate it (Lazarus, 1993; Aspinwall, Taylor, 1997; Kornilova, 2016; Bityutskaya, Korneev, 2020, etc.); the system-subjective approach, which assumes that the subjects themselves and their subjective properties (control, higher motives, proactivity and others) are the system-forming factors of proactive or reactive coping (Sergienko, 2009; Belinskaya et al., 2018; Slabinsky et al., 2019 ; Kuftyak, 2019; Bekhter, 2019); the resource classical approach, which is focused on the allocation of key resources in proactive and reactive coping behaviors, such as time perspective, reflexivity, subjectivity, hardiness, etc. (Starchenkova, 2009; Korzun, 2016; Bekhter, Filatova, 2018; Belinskaya et al., 2019; Sekatskaya, 2020). Many authors adhere to an integrative approach to the problem of proactive and reactive coping, since these two types of behavior, in their opinion, have a single development path (Slabinsky et al., 2019; Starchenkova, 2012; Kuftyak, Bekhter, 2020).

Proactive coping behavior is described within the framework of the fivefactor model (Aspinwall, Taylor, 1997), three-factor model (Starchenkova, 2012) and level model (Slabinsky et al., 2019). The five-factor model includes several types of proactive coping: (1) proactive, (2) preventive, (3) reflexive, (4) strategic planning, and (5) seeking emotional and informational support (Aspinwall, Taylor, 1997; Greenglass et al., 1999; Schwarzer, 2001). Cognitive processes by which people prevent stressful events, and also act in advance to prevent their occurrence, can also be proactive (Kornilova, 2016). With the aim of changing unavoidable stressful situations, proactive coping can eliminate stress long before it occurs. Skills associated with this behavior include planning, setting goals, and mentally simulating an event (Aspinwall, Taylor, 1997). Preventive coping as part of proactive behavior refers to the process by which a person builds up resources and resists "just to be safe" with potential stressors that will occur in the distant future. This type of behavior involves risk management, but in this case, the risk is not explicitly expressed. Reflective coping is interpreted by E.S. Starchenkova (2012) as an idea and reflection on possible behavioral alternatives by comparing their possible effectiveness. It includes assessing stressors, analyzing problems and available resources, generating a proposed action plan, predicting the probabilistic outcome of an activity and choosing ways to perform it (perspective reflection).

One of the most important processes of proactive coping behavior is strategic planning, which is the creation of a well-thought-out, goal-oriented plan of action. Large-scale goals are subdivided into sub-goals (goal tree), the management of the achievement of which becomes more accessible. Seeking help from information resources (the Internet, social networks, books, etc.) characterizes the strategy of seeking information support, the main purpose of which is to find information on how to overcome a future stressful situation. Seeking emotional support is a strategy aimed at regulating temporary negative emotional states by revealing their experiences to others in order to gain compassion, support or advice (Vaculikova, 2016). 
In proactive coping behavior, there are four features that distinguish it from reactive coping behavior: (1) combining planning strategies with the regulation of achieving set goals, (2) achieving goals using social resources, (3) using emotional coping to achieve set goals, and (4) focusing on the "future" time perspective (Korzun, 2016; Sekatskaya, 2020). Thus, proactive coping behavior provides a better opportunity for personal growth and self-development than reactive coping.

The level organization of coping behavior is presented by several authors. In the works of V.Yu. Slabinsky et al. (2019), the level of coping is associated with the level of life functioning and includes reactive, active and proactive coping. The authors do not exclude the possibility that there are transitional forms between these types of behavior, since coping behavior is a dynamic phenomenon in a changing complex situation (Slabinsky et al., 2019). E.S. Starchenkova argues that coping behavior can be subdivided into reactive, anticipatory-preventive, and proactive ones (Starchenkova, 2009, 2012). In our work, we will rely on the level model proposed by V.Yu. Slabinsky when interpreting cluster analysis.

Among interesting models of reactive coping, one can single out the model of differentiated reactivity, which correlates the use of strategies, the time perspective, and the actual effectiveness of coping strategies (Bolger, Zuskerman, 1995). The authors believe that people can influence the impact of a stressor, their response to stressors, and the effectiveness of the chosen strategies. Based on this concept, four models of reactive behavior have been described (Bolger, Zuskerman, 1995).

Studies of students' proactive coping behavior have shown that its strategies are associated with temporary perspective, self-regulation, hardiness and proactivity (Bekhter, Golovacheva, 2020; Bekhter, Prokhorova, 2020). It is also found that the level of stress influences the choice of strategies for reactive and proactive coping: students with a low level of stress choose strategies of proactive coping, while those with a high level seek informational support. It is stated that insufficient life experience at a young age (from 18 to 24 years) is the reason for the difficulty in the formation of proactive forms of coping (Kuftyak, 2019; Kuftyak, Bekhter, 2020). Other studies show that first-year students (especially young men) are more likely to choose the reflective coping strategy (Korzun, 2016).

In view of the above, we have identified the target guidelines for the applied research, the results of which are proposed in this article:

1) to theoretically substantiate the problem of reactive and proactive coping behavior of first-year students;

2) to select research methods for diagnosing reactive and proactive coping behavior and to test the corresponding instrumentation in an empirical study on a sample of first-year students in two groups: experimental (the students underwent individual counseling, participated in self-help groups and trainings) and control (the students who voluntarily participated in a psychodiagnostic study);

3 ) to determine the links between the parameters of reactive and proactive coping behavior of the students in the experimental group, identify and describe the personality types of the students on the basis of primary diagnostics;

4) to identify changes in the proactive and reactive coping behaviors of the students in the experimental group due to the provision of various forms of 
psychological support (through repeated diagnostics), draw conclusions about the appropriateness of the appropriate forms of psychological support for this sample, and compare the experimental and control groups upon completion of the work.

\section{Methods}

Participants. The study of proactive and reactive coping behavior involved 136 first-year students aged $17-18$ years $(\mathrm{M}=18.5$; $\mathrm{SD}=0.66)$ from various faculties of the Pacific National University (PNU), who applied for help at the University Psychological Center in 2019 (experimental group). All the participants voluntarily underwent preliminary and final diagnostics; a consent for processing data and an agreement for providing psychological services were issued for each student (according to the rules of the Center and the internal regulations of PNU).

The control group consisted of 136 first-year students from various faculties of PNU $(\mathrm{M}=18.3 ; \mathrm{SD}=0.51)$, who voluntarily underwent diagnostics as part of the annual examination of freshmen.

According to the forms of psychological assistance provided, the students were distributed as follows: 58 students were on individual counseling according to Nossrat Peseschkian's Positive Psychotherapy (PPT) method (of which 18 people limited themselves to 1-2 consultations (later they went for psychotherapy to outside psychotherapists), 32 students regularly went on consultations during the year), 8 people received psychological and psychiatric assistance and drug treatment in view of an aggravated mental state (theses students already entered the university with diagnoses F.32.10, F.31.3, F.34., F.42.0, received melipramine, fevarin, chlorprothixene) according to the agreement of gratuitous services between the university and the krai government-owned publicly funded health care institution "Regional Clinical Psychiatric Hospital" of the Ministry of Health of the Khabarovsk territory. Drug treatment improved (compensated) the condition of only five students out of eight; three students went on an academic leave in the second term due to a severe psycho-emotional state (diagnosis F.31.3). The criterion for uniting students in this group is a certain psychotype (described in the cluster analysis) and the nature of the trauma when they were seeking help (as a rule, violence or codependent relationships).

Programs for reflective training, stress coping and proactive coping behavior development (with techniques and techniques of positive psychotherapy, cognitive-behavioral psychotherapy, art therapy), recommendations for managing self-help groups (according to the PPT method) are based on the authors' tested developments, approved by the scientific council of the university and included in the nomenclature of the Psychological Center of PNU as operating programs group activities (Bekhter, 2017a, 2017b). 30 students participated in self-help groups (14 students in the first term and 16 students in the second term) based on the method of positive psychotherapy; the main topics of the meetings were interpersonal relationships with relatives and close friends; 16 students participated in reflective training; 18 people participated in stress coping training; and 14 students attended proactive coping training. Self-help groups as such are mainly focused on group support and designed to practice behavioral skills.

The indications for individual counseling of the students were: requests, severe emotional states (acute trauma or loss, exacerbation of mental illness), inabil- 
ity to work in a group due to a certain emotional state, unwillingness to work in a group. For group activities, the students were selected according to the following criteria: requests, willingness to work in a group, a desire to attend certain training, a relatively stable emotional state, a similar topic of problems. We also took into account the individual results of the students' diagnostics when forming the groups and trainings (introducing additional exercises, planning the course of the lessons, changing the topics of the lessons).

We summarized the main requests, and they were divided as follows: "problems with parents" (40 people), "bad mood" ( 25 people), "problems with an intimate partner" (16 people), "suicidal thoughts" (12 people), "constant anxiety attacks" (12 people), "problems with groupmates" (10 people), "problems with roommates in a dormitory" (7 people), "fear of the future and the unknown" (8 people), and "difficulties in understanding oneself and one's actions" (6 people). The students having the most difficult requests (psychological trauma, suicidal thoughts, mood and behavior disorders) attended individual consultations, the rest of the students after 1-2 initial individual consultations moved to training or self-help groups.

Procedure. The study was conducted in the following stages:

1) performing primary diagnostics of reactive and proactive coping behaviors of the students in the control and experimental groups, analyzing their requests, interviewing (by the psychologists of the Center);

2) identifying relationships between the parameters of reactive and proactive coping behaviors of the students in the experimental group, revealing and descrybing personality types of the students based on primary diagnostics to determine "sensitive" targets for psychological assistance;

3) providing psychological assistance to the students in the experimental group through various forms of individual and group work; and

4) performing re-diagnostics of reactive and proactive coping behaviors of the students in the experimental group in order to determine behavioral and personal changes.

Diagnostic methods. The following diagnostic tools were used to assess behavior and personality characteristics:

1) Proactive Coping Inventory (PCI) (adapted by E.P. Belinskaya et al., 2018) to determine strategies for proactive coping. This technique includes the following six scales: "Proactive coping" $(\min =25 ; \max =44 ; \mathrm{M}=36.60 ; \mathrm{SD}=4.81)$; "Reflective coping" $(\min =20 ; \max =41 ; \mathrm{M}=31.20 ; \mathrm{SD}=6.39)$; "Strategic planning" $(\min =5 ; \max =16 ; \mathrm{M}=10.00 ; \mathrm{SD}=3.13)$; "Preventive coping" $(\min =17$; $\max =40 ; M=28.18 ; \mathrm{SD}=5.93)$; "Seeking informational support" $(\min =8$; $\max =30 ; \mathrm{M}=18.68 ; \mathrm{SD}=4.91)$; and "Seeking emotional support" $(\min =6$; $\max =20 ; \mathrm{M}=13.31 ; \mathrm{SD}=3.79)$;

2) Ways of Coping Questionnaire by R. Lasarus (adapted by T.L. Kryukova et al.) - to determine the main coping strategies. It includes the following eight scales: "Confrontation" $(\min =1 ; \max =16 ; \mathrm{M}=8.98 ; \mathrm{SD}=2.68)$; "Distancing" $(\min =1 ; \max =17 ; \mathrm{M}=8.78 ; \mathrm{SD}=3.01)$; "Self-control" $(\min =1 ; \max =21$; $\mathrm{M}=13.73$; $\mathrm{SD}=3.11)$; "Seeking social support" $(\min =1 ; \max =18 ; \mathrm{M}=10.63$; $\mathrm{SD}=3.31)$; "Taking responsibility" $(\min =1 ; \max =12 ; \mathrm{M}=7.41 ; \mathrm{SD}=2.18)$; "Escape-avoidance" $(\min =3 ; \max =23 ; \mathrm{M}=10.53 ; \mathrm{SD}=3.52)$; "Problem solu- 
tion planning" $(\min =3 ; \max =18 ; \mathrm{M}=12.73 ; \mathrm{SD}=2.97)$; and "Positive problem reassessment" $(\min =3 ; \max =21 ; \mathrm{M}=12.01 ; \mathrm{SD}=3.48)$;

3) Hardiness Survey by S. Maddi (adapted by D.A. Leontyev and E.I. Rasskazova, 2006) - to determine the level of hardiness and its parameters. It includes the following four scales: "Commitment" $(\mathrm{M}=35.78$; $\mathrm{SD}=7.43)$; "Control" $(\mathrm{M}=29.33$; $\mathrm{SD}=9.24)$; "Challenge" $(\mathrm{M}=18.19 ; \mathrm{SD}=5,04)$; and "Hardiness" $(\mathrm{M}=83.3 ; \mathrm{SD}=18.00)$;

4) Time Perspective Inventory (TPI) by Ph. Zimbardo (adapted by A. Syrtsova et al., 2008) - to determine the leading time perspective. It includes the following five scales: "Negative past" $(\min =1 ; \max =4,20 ; \mathrm{M}=2.5 ; \mathrm{SD}=0.59)$ "Hedonistic present" $(\min =2.10 ; \max =4.90 ; \mathrm{M}=3.42 ; \mathrm{SD}=0.56)$; "Future" $(\min =1.04 ; \max =4.80 ; \mathrm{M}=3.48 ; \mathrm{SD}=0.62) ;$ "Positive past" $(\min =2$; $\max =5 ; \mathrm{M}=3.68 ; \mathrm{SD}=0.57)$; and "Fatalistic present" $(\min =1 ; \max =4.60$; $\mathrm{M}=2.68 ; \mathrm{SD}=0.61$ ).

5) Reflexivity Diagnostics Method by A.V. Karpov (2003) - to determine the reflexivity level. It includes one scale: "Reflectivity" $(\min =0 ; \max =10$; $\mathrm{M}=4.82$; $\mathrm{SD}=2.18$ ).

Practical methods. The following forms and techniques of providing psychological assistance were used: a) individual counseling; b) self-help groups (with the aim of solving current emotional problems and situations); c) reflective training (focused on the development of reflective skills and abilities); d) stress coping training (in order to increase coping resources); e) proactive coping training (focused on the development of predicting and goal-setting).

Statistical methods. The methods of descriptive statistics, Spearman's rank correlation analysis, k-mean clustering, sign test (Z), and Mann - Whitney $U$-test were used for statistical data processing. The calculations were carried out using the SPSS Statistics 24.0 software package.

\section{Results and discussion}

General descriptive statistics of the experimental and control groups are presented in Tab. 1. The distribution of all the parameters (signs) measured by criterion analysis (skewness and kurtosis) is close to normal, except for parameters 4 and 18 ("Strategic planning" and "Control", kurtosis is greater than 1 and -1). For this reason, in subsequent comparisons of the groups, the Mann - Whitney $U$-test was used for independent samples.

The Mann - Whitney $U$-test made it possible to confirm the differences between the groups. In the experimental group, the scores for the reactive escapeavoidance strategy $(U=230$ at $p \leq 0.01)$ and the general indicator of hardiness $(U=279$ at $p \leq 0.05)$ turned out to be higher, which indicates in favor of insufficient skills to cope with stress and problems, despite on the resource of hardiness. The control group has higher indicators in proactive coping $(U=685$ at $p \leq 0.01)$, strategic planning $(U=147$ at $p \leq 0.05)$, seeking for emotional $(U=248$ at $p \leq 0.05)$ and social support $(U=295$ at $p \leq 0.05)$, Problem solution planning $(U=189$ at $p \leq 0.05)$, reflexivity $(U=271$ at $p \leq 0.01)$ and the "Positive past" time perspective $(U=137$ at $p \leq 0.01)$ (Table 1$)$, which allows it to be more adaptive. 
Means, standard deviations, skewness, kurtosis, and Mann - Whitney' U-test for study variables in experimental and control groups

\begin{tabular}{|c|c|c|c|c|c|c|c|c|c|}
\hline \multirow{2}{*}{ Indicators } & \multicolumn{4}{|c|}{$\begin{array}{l}\text { Experimental group, } \\
\qquad N=136\end{array}$} & \multicolumn{4}{|c|}{$\begin{array}{c}\text { Control group, } \\
\qquad N=136\end{array}$} & \multirow{2}{*}{$\begin{array}{c}\begin{array}{c}\text { Mann - } \\
\text { Whitney' } \\
\text { U-test }\end{array} \\
U\end{array}$} \\
\hline & M & SD & $A$ & $E$ & M & SD & $A$ & $E$ & \\
\hline 1. Age & 18.05 & 0.66 & -0.13 & -0.39 & 18.30 & 0.51 & -0.67 & -0.76 & 151 \\
\hline 2. Proactive coping & 36.47 & 4.67 & 0.00 & -0.69 & 39.26 & 5.69 & -0.13 & -0.08 & $675^{\star *}$ \\
\hline 3. Reflective coping & 31.36 & 6.14 & 0.31 & 0.41 & 30.00 & 6.84 & -0.20 & -0.42 & 108 \\
\hline $\begin{array}{l}\text { 4. Strategic } \\
\text { planning }\end{array}$ & 9.77 & 3.00 & 0.30 & 0.22 & 10.05 & 4.29 & 1.42 & 1.13 & $147^{*}$ \\
\hline 5. Preventive coping & 28.23 & 5.78 & 0.03 & -0.72 & 28.03 & 5.62 & -0.18 & 0.13 & 140 \\
\hline $\begin{array}{l}\text { 6. Seeking informa- } \\
\text { tional support }\end{array}$ & 18.88 & 5.27 & -0.06 & -0.63 & 19.12 & 4.28 & 0.26 & -0.04 & 150 \\
\hline $\begin{array}{l}\text { 7. Seeking emo- } \\
\text { tional support }\end{array}$ & 13.40 & 3.79 & -0.05 & -0.00 & 13.43 & 3.41 & -0.25 & -0.17 & $248^{*}$ \\
\hline 8. Confrontation & 9.22 & 3.23 & -0.04 & -0.21 & 12.93 & 1.59 & 0.29 & 0.35 & 219.50 \\
\hline 9. Distancing & 9.80 & 3.32 & -0.80 & 0.52 & 6.15 & 3.96 & -0.12 & 0.05 & 167 \\
\hline 10. Self-control & 12.63 & 3.46 & 0.32 & 0.35 & 11.54 & 6.70 & -0.06 & -0.21 & 103 \\
\hline $\begin{array}{l}\text { 11. Seeking } \\
\text { social support }\end{array}$ & 10.34 & 3.74 & -0.37 & -0.54 & 11.62 & 6.04 & -0.31 & 0.23 & $295^{*}$ \\
\hline $\begin{array}{l}\text { 12. Taking respon- } \\
\text { sibility }\end{array}$ & 8.00 & 2.34 & -0.13 & -0.37 & 6.56 & 4.76 & -0.47 & 0.23 & 89 \\
\hline $\begin{array}{l}\text { 13. Escape- } \\
\text { avoidance }\end{array}$ & 13.61 & 4.38 & -0.22 & -0.07 & 11.68 & 3.91 & -0.21 & 0.32 & $230^{* *}$ \\
\hline $\begin{array}{l}\text { 14. Problem } \\
\text { solution planning }\end{array}$ & 11.22 & 3.62 & -0.24 & -0.32 & 14.53 & 7.06 & 0.146 & 0.31 & $189^{*}$ \\
\hline $\begin{array}{l}\text { 15. Positive prob- } \\
\text { lem reassessment }\end{array}$ & 12.51 & 3.76 & -0.11 & -0.82 & 13.43 & 2.17 & -0.20 & -0.64 & 145.5 \\
\hline 16. Reflexivity & 4.97 & 2.13 & 0.14 & 0.56 & 5.67 & 1.55 & -0.34 & 0.38 & 271 ** \\
\hline 17. Commitment & 31.28 & 10.16 & 0.01 & -0.89 & 31.33 & 32.00 & -0.52 & 0.04 & 138 \\
\hline 18. Control & 26.10 & 8.62 & -0.16 & -1.15 & 26.43 & 27.00 & -0.12 & -0.17 & 160 \\
\hline 19. Challenge & 15.50 & 5.02 & -0.18 & -0.57 & 15.60 & 16.00 & -0.26 & -0.15 & 136 \\
\hline 20. Hardiness & 69.26 & 22.49 & -0.09 & -0.73 & 68.52 & 71.00 & -0.43 & -0.05 & $278^{*}$ \\
\hline 21. Negative past & 3.45 & 0.98 & -0.06 & -0.64 & 2.8 & 1.00 & -0.07 & -0.07 & 126 \\
\hline $\begin{array}{l}\text { 22. Hedonistic pre- } \\
\text { sent }\end{array}$ & 4.5 & 0.31 & -0.28 & 0.26 & 3.1 & 1.12 & -0.42 & -0.29 & 142 \\
\hline 23. Future & 4.1 & 0.49 & -0.03 & -0.31 & 4.4 & 0.22 & -0.12 & -0.03 & 121 \\
\hline 24. Positive past & 3.1 & 0.30 & -0.31 & -0.25 & 3.8 & 0.06 & -0.33 & -0.30 & $137^{* *}$ \\
\hline 25. Fatalistic present & 2.5 & 1.08 & -0.18 & -.023 & 2.3 & 0.36 & -0.45 & 0.18 & 133 \\
\hline
\end{tabular}

Note: ${ }^{\star} p \leq 0.05 ;{ }^{*} p \leq 0.01 . \mathrm{M}-$ mean, SD - standard deviation, $A$-skewness, $E$ - kurtosis 
Spearman's rank correlation analysis revealed many significant positive relationships between the strategies of reactive-proactive coping and the parameters of the time perspective in the students of the experimental group (Table 2). Here one can see a kind of "ontogeny" of proactive coping. The three basic types of support - social, informational and emotional - are interconnected and represent the main "platform" for the subsequent development of planning strategies.

The search for social support correlates with emotional support $\left(r_{s}=0.700\right)$, with the fatalistic present $\left(r_{s}=0.229\right)$, with the positive past $\left(r_{s}=0.267\right)$ and the negative past $\left(r_{s}=0.353\right)$; the search for emotional support correlates with the positive past $\left(r_{s}=0.281\right)$, the search for informational support is significantly associated with the search for emotional support $\left(r_{s}=0.498\right)$ and social support $\left(r_{s}=0.658\right)$, the negative past $\left(r_{s}=0.349\right)$, the fatalistic present $\left(r_{s}=0.229\right)$, the hedonistic present $\left(r_{s}=0.341\right)$, and self-control $\left(r_{s}=0.650\right)$. These correlations allow us to conclude that the students seek social support as a basic type of help in cases of positive and negative past experiences as well as in the experience of the uncontrollability (fatality) of the present. Consequently, the search for social support as a strategy of reactive coping, the search for emotional and informational support as a type of proactive coping are closely related to the positive experience of receiving any support in the past. To a greater extent, the students implement this experience in the present as "familiar" and "proven" coping strategies, even if they do not improve the course of a difficult situation. It is worth noting that seeking information can help strengthen self-control in a difficult situation for a while. Emotional and informational supports as components of proactive coping behavior are associated with the time perspective parameters. This fact suggests that it is important for a student to have the ability to establish cause-andeffect relationships at the "past-present-future" level in order to implement such strategies for seeking help, since the experience of time is one of the significant resources of proactive coping behavior (Starchenkova, 2009; Sekatskaya, 2020).

All the types of support are interconnected with the reactive behavior strategies, which are prerequisites for proactive behavior: Problem solution planning, positive problem reassessment and self-control are associated with emotional support $\left(r_{s}=0.25 ; r_{s}=0.36\right.$ and $r_{s}=0.70$, respectively).

Problem solution planning and positive problem reassessment as strategies are developed on the basis of the time perspective and are naturally associated with the positive past $\left(r_{s}=0.28 ; r_{s}=0.29\right)$ and the hedonistic present $\left(r_{s}=0.27\right.$, $\left.r_{s}=0.25\right)$ and the future $\left(r_{s}=0,49 ; r_{s}=0,37\right)$. These signs are consistent with the manifestation of active coping, where the hedonistic present (and partly the future) is one of the main guidelines for a student (Slabinsky et al., 2019).

Problem solution planning is associated with proactive $\left(r_{s}=0.31\right)$, reflective $\left(r_{s}=0.45\right)$, preventive coping $\left(r_{s}=0.51\right)$ and strategic planning $\left(r_{s}=0.49\right)$, which indicates its important role in the formation of strategies for the accumulation of resources and analysis of the future situation. Positive problem reassessment is also involved in building proactive strategies; to a lesser extent, but it is still associated with strategic planning $\left(r_{s}=0.38\right)$, reflective $\left(r_{s}=0.32\right)$, preventive $\left(r_{s}=0.36\right)$ and proactive $\left(r_{s}=0.37\right)$ coping. 
Table 2

Spearman's correlations between parameters of reactive and proactive coping, hardiness, reflexivity and time perspective in the experimental group

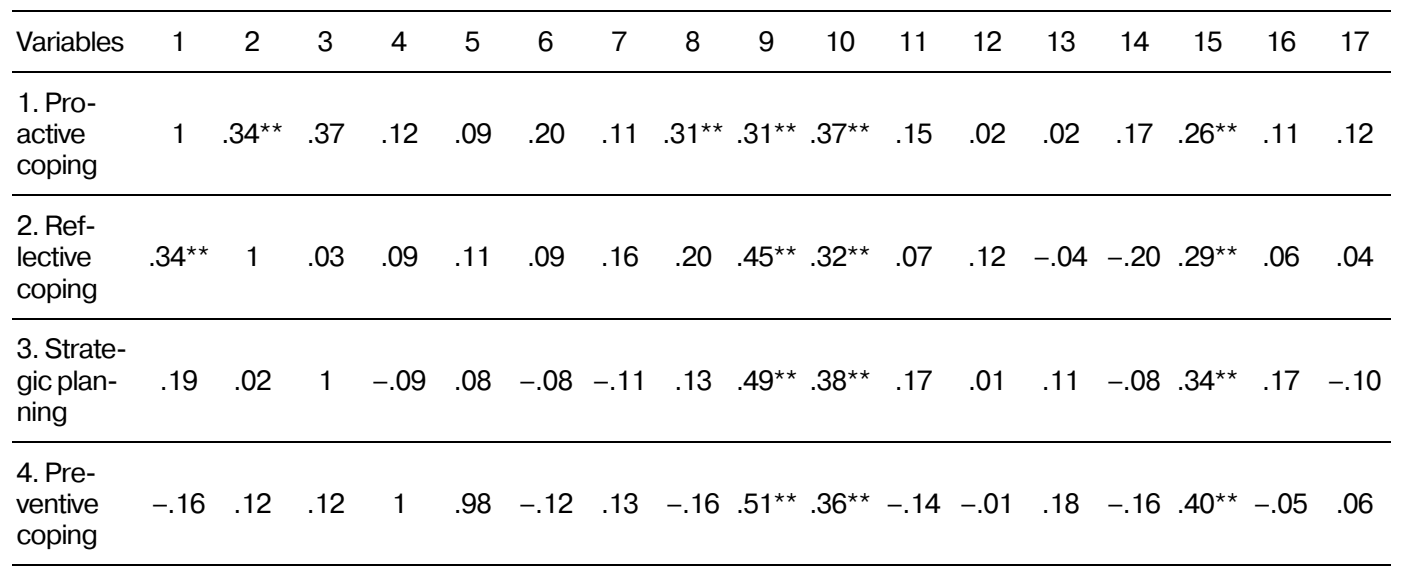

5. See-

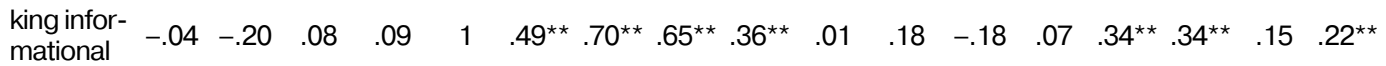
support

6. See-

$\begin{array}{lllllllllllllllllllll}\text { king emo- } & -.02 & -.04 & .07 & -.11 & .49^{\star *} & 1 & .20 & .70^{\star *} & .30^{\star *} & .36^{\star *} & -.00 & .11 & -.01 & -.20 & - & .09 & .28^{\star *}\end{array}$ port

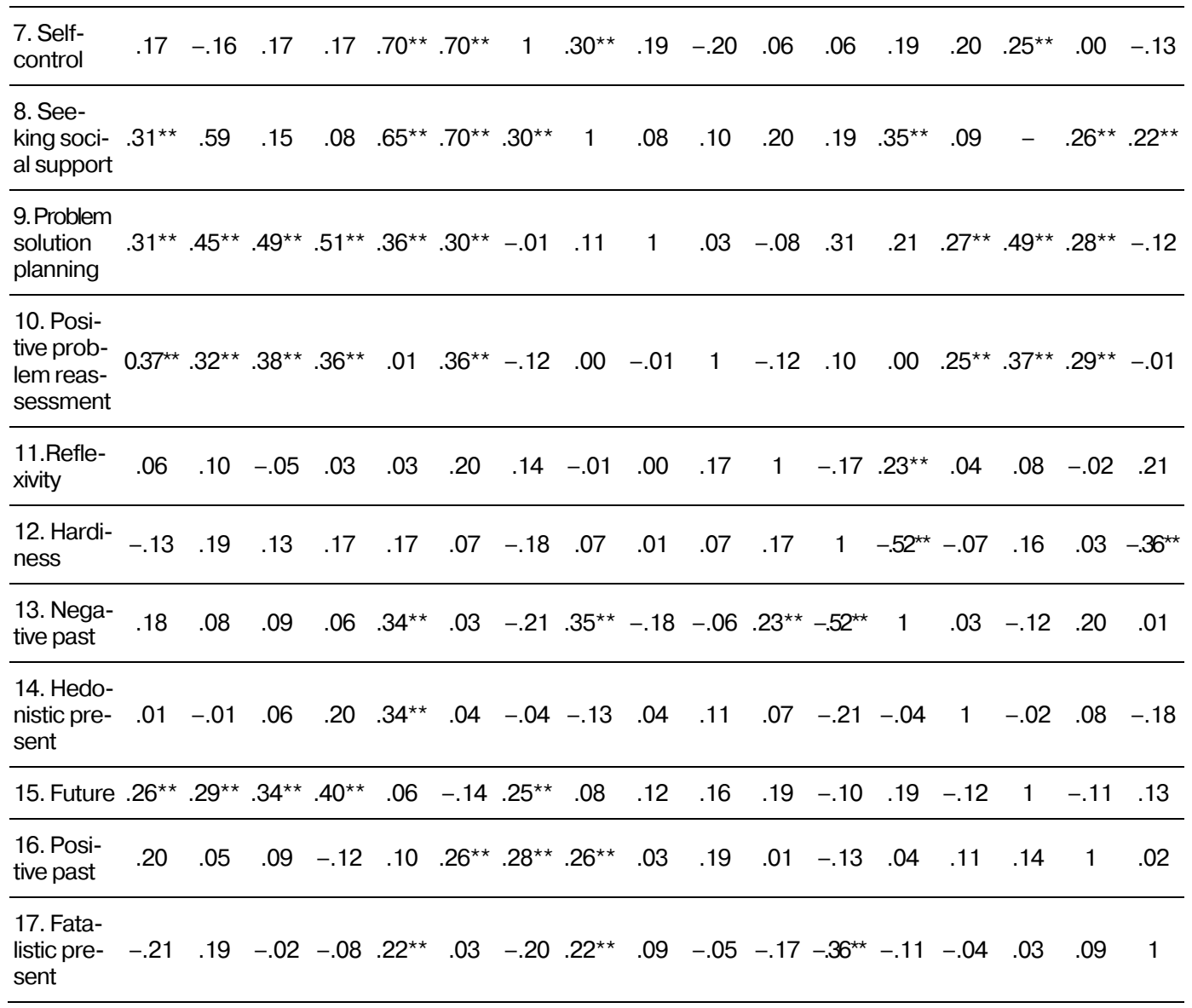

Note: ${ }^{*} p \leq 0.05 ;{ }^{* \star} p \leq 0.01$. 
A special component is the category of the future, which has interrelationships with proactive $\left(r_{s}=0.26\right)$, preventive $\left(r_{s}=0.40\right)$, reflective coping $\left(r_{s}=0.29\right)$, strategic planning $\left(r_{s}=0.34\right)$ and self-control $\left(r_{s}=0.25\right)$. We assume that selfcontrol as a reactive strategy in this sample is moderating in relation to all types of proactive coping. The important role of control and self-control in coping behavior has received much attention in the studies of other authors (Sergienko, 2009).

Among the significant negative relationships (at $p \leq 0.01$ ) we can note the correlations of hardiness with the negative past $\left(r_{s}=-0.52\right)$ and the fatalistic present $\left(r_{s}=-0.36\right)$. We suppose that this may be due to the mechanism of the formation of hardiness in the student's experience, i. e., experiencing negative events in the past and rethinking the fatality of the present increase hardiness, thereby subsequently reducing the intensity in one's own understanding of the "negative past" and "fatalistic present". General reflexivity positively associated with the negative past $\left(r_{s}=0.23\right)$ acts as a tool for analyzing events and is important for developing hardiness parameters.

Further, the obtained data were subjected to cluster analysis to identify groups (clusters) of the students based on the differences between reactive and proactive coping behavior. Three clusters of the experimental group were obtained by the method of $k$-mean clustering (Figure).

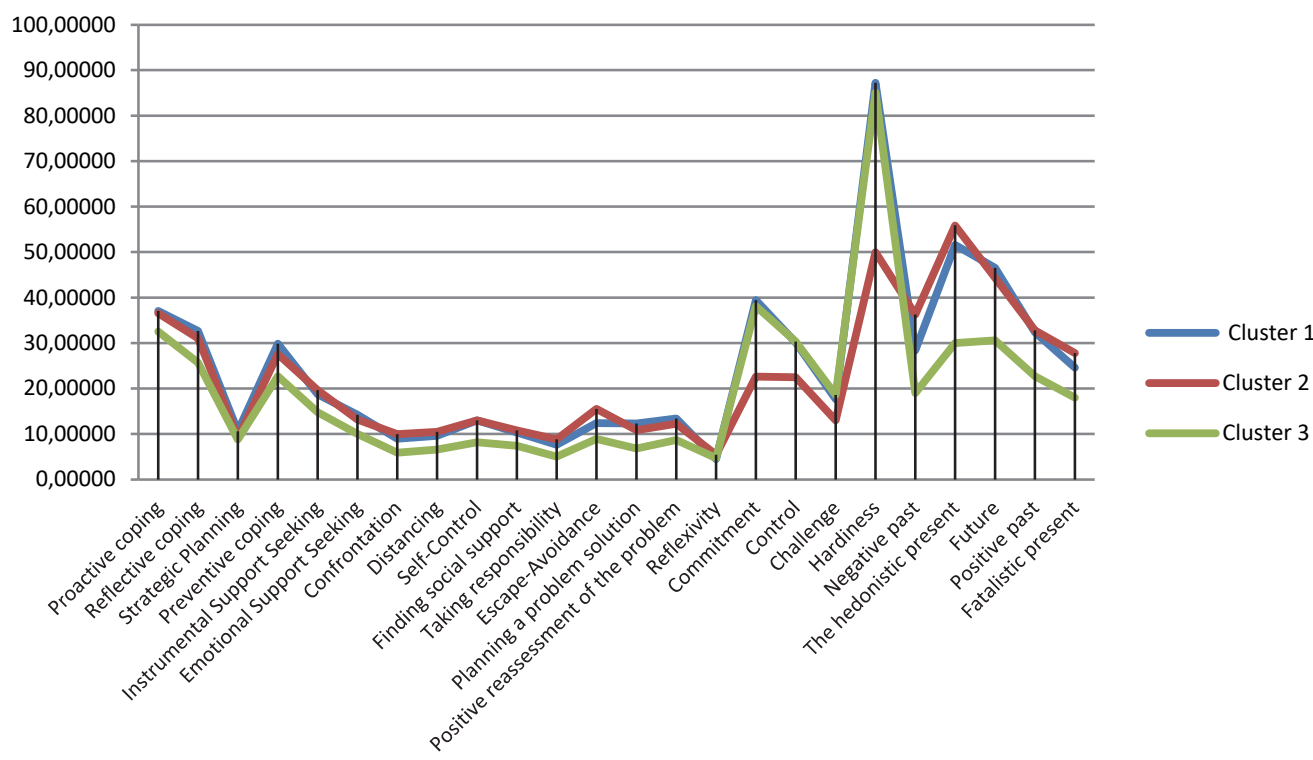

Figure. Graph of "averages" for each cluster

The first cluster includes 61 students aged 17, who subsequently attended one-time individual consultations (18 people) and subsequently attended proactive coping training (14 people), reflexive training (16 people), and a self-help group (13 people). This group of students is characterized by high indicators on the scales of proactive and reactive coping, which are associated with problem solution planning and positive problem reassessment. These students are also distinguished by high hardiness (due to high involvement and risk-taking) and temporary orientation towards the present-future. A pronounced component of the hedonistic present and 
a reduced component of the negative past indicate a formed active type of coping (Slabinsky V.Yu. et al., 2019). At the same time, the indicators of orientation towards the future are also high, which may indicate the transition of active coping to proactive coping. We designated this type as "active with a proactive trend".

The second cluster includes 65 students (average age $=18$ years), who subsequently attended individual counseling (30 people), stress coping training (18 people) and a self-help group (17 people). This cluster is distinguished by a pronounced reactive type of behavior compared to other clusters (the highest scores for confrontation, escape, distancing, and self-control) with a specific temporal perspective: the predominance of the hedonistic present component combined with a fatalistic one bias towards the negative past (in comparison with other clusters), which corresponds to the results obtained by V.Yu. Slabinsky et al. (2019). Hardiness in this group is less pronounced due to the reduced indicators of challenge and commitment. The indicators of proactive coping are lower than in the first cluster but higher than in the third one. It should be noted that the strategies of positive problem reassessment and problem solution planning as prerequisites for proactive coping were also not expressed. The type of students in this cluster can be designated as "reactive", which combines some ability to choose a strategy of behavior and predict its effectiveness.

The third cluster includes students (girls, average age being 18 years) receiving individual psychological assistance combined with psychiatric-psychotherapeutic intervention ( 8 people) and 2 students who regularly visited a psychologist throughout the year. This group of students had the lowest rates of reactive and proactive behavior compared to the other clusters. But the overall indicator of hardiness (commitment, control, challenge) turned out to be unexpectedly high against the background of the average level of reflexivity. The time perspective was not expressed, the indicators of the future, hedonistic present and negative past were low. According to the available research data, this may indicate affective disorders (Zakharova, Trusova, 2019). This is confirmed by the students' anamnestic data (8 cases with F.32.1 diagnosis (moderate depressive episode), 2 cases with adaptation difficulties). Such students live outside of time, their only task becomes survival and formal behavior (eating, visiting the university, minimal communication). The high level of hardiness of these students also correlates with their state of mind "to hold out to the last" at the level of the attitude, to grab onto saving themselves by receiving psychological, psychiatric and psychotherapeutic help. This type can be designated as "non-adaptive", since all the behavioral strategies are not only ineffective but also do not lead to problem solving, and even worsen the condition of such students.

The final stage of our work was to conduct a repeated study of the students in the experimental group according to the parameters of reactive and proactive coping and compare the results before and after psychological intervention. The results were analyzed using a nonparametric sign test, taking into account the heterogeneity of the sample.

As Table 3 shows, individual counseling as a whole has an impact only on strengthening self-control and control but, at the same time, reduces the significance of the negative past and the fatalistic present. These results should be con- 
sidered very important, as they will allow students from this group to subsequently join trainings and self-help groups. The self-help group allowed the students to optimize the parameters of hardiness, which is an important resource in coping behavior, contributing to the development of self-confidence and self-efficacy. Reflexive training made it possible to increase the indicator of reflexivity, expand the possibilities of informational support and, due to this, probably reduce the need for social support.

Table 3

Statistically significant differences in the parameters of proactive and reactive coping, hardiness, time perspective of the students in the experimental group before and after psychological care

\begin{tabular}{|c|c|c|c|c|}
\hline \multirow{2}{*}{ Indicators } & \multicolumn{2}{|c|}{ Means } & \multirow{2}{*}{ Difference } & \multirow{2}{*}{$Z$ (sign test) } \\
\hline & Before & After & & \\
\hline \multicolumn{5}{|c|}{ Individual counseling ( $n=58$; at $p \leq 0.01)$} \\
\hline Self-control & 12.6 & 15.1 & +2.5 & 2.21 \\
\hline Negative past & 31.4 & 29.0 & -2.4 & 2.77 \\
\hline Control & 26.0 & 35.4 & -9.4 & 2.59 \\
\hline Fatalistic present & 40.3 & 36.2 & -4.1 & 3.32 \\
\hline \multicolumn{5}{|c|}{ Self-help group ( $n=30$; at $p \leq 0.01)$} \\
\hline Commitment & 33.2 & 36.7 & +3.5 & 2.27 \\
\hline Control & 30.0 & 33.5 & +3.5 & 2.23 \\
\hline Challenge & 17.7 & 22.2 & +4.5 & 2.47 \\
\hline Hardiness & 80.5 & 92.5 & +11.6 & 2.47 \\
\hline \multicolumn{5}{|c|}{ Reflective training ( $n=16$; at $p \leq 0.05)$} \\
\hline Reflexivity & 4.9 & 5.6 & +0.7 & 1.20 \\
\hline Seeking social support & 10.5 & 9.1 & -1.4 & 1.10 \\
\hline Seeking informational support & 18.4 & 26.2 & +7.8 & 3.32 \\
\hline \multicolumn{5}{|c|}{ Stress coping training $(n=18 ;$ at $p \leq 0.01)$} \\
\hline Preventive coping & 28.2 & 35.6 & +7.4 & 2.21 \\
\hline Escape-avoidance & 13.6 & 12.8 & -0.8 & 2.25 \\
\hline Problem solution planning & 11.2 & 14.2 & +3.0 & 2.21 \\
\hline Fatalistic present & 20.3 & 18.1 & -2.2 & 2.77 \\
\hline \multicolumn{5}{|c|}{ Proactive coping training $(n=14 ;$ at $p \leq 0.01)$} \\
\hline Hedonistic present & 55.6 & 60.1 & +4.5 & 3.32 \\
\hline Reflective coping & 31.36 & 34.6 & +3.0 & 3.32 \\
\hline Strategic planning & 9.7 & 14.5 & +4.8 & 3.32 \\
\hline
\end{tabular}

We can regard the students' increased indicators of preventive coping and problem solution planning in stress coping training as a positive sign against the reduced indicators of the fatalistic present and escape-avoidance. Proactive 
training influenced the optimization of reflective coping, strategic planning and the increase in the indicators of the hedonistic present. We associate these phenomena with integral stages in the development of proactive coping: from reactive behaviors (dominated by the negative past and the fatalistic present) to active strategies (dominated by the hedonistic present and the trend towards the future).

Thus, it should be stated that group training activities develop more competitive strategies at the behavioral level and change the attitude towards the category of time. Individual counseling and self-help groups are more conducive to the development of personal coping resources (hardiness, reflexivity, self-control), they also change attitudes towards time and allow people to look differently at the cause-and-effect relationships of their life events.

\section{Conclusion}

The performed theoretical analysis and applied empirical research allow us to formulate the following conclusions, reflecting the results of studying the features of diagnostics and the possibilities of developing reactive and proactive behavior in first-year students in the real practice of the psychological service at a higher educational institution.

Reactive and proactive coping behaviors are aimed at overcoming difficult and stressful situations: in the first case, with an orientation towards past experience using reactive strategies, in the second case, with a focus on the future using proactive strategies.

The level of reactive-proactive strategies and personal resources makes it possible to classify students who received psychological assistance into three types: non-adaptive, reactive and active with a proactive trend. Thus, we can conclude that individual counseling is indicated to the non-adaptive type of students, self-help groups and trainings on developing reflexivity and stress coping in combination with individual counseling on request are suitable for the reactive type, and all group activities, especially trainings on developing forecasting and reflexivity are suitable for the active type.

A specific feature of reactive and proactive coping in the experimental group is the prevalence of different types of support - social, emotional and informational, which are connected with each other and with personal resources. An important prerequisite for the formation of reactive and proactive strategies is the awareness of the choice of behavior strategies, their temporal orientation, and effectiveness in a particular situation. Therefore, teaching students the skills of planning, forecasting and reflecting is an important stage in the transition from reactive to proactive coping.

Forms of psychological support have different effects on the development of coping behavior in students: individual counseling and self-help groups are more preferable for the development of reactive forms of coping, whereas trainings aimed at developing reflexivity, planning and forecasting are useful for the formation of active and proactive strategies. 
Evaluating the possibilities of our efforts in group and individual forms of psychological support for the students of the experimental group, we can state a positive dynamics in the development of some strategies of both reactive and proactive coping behavior as well as changes in time perspective. The lack of a representative sample does not allow us to generalize the research results, regarding the proposed methods of work as universal with all categories of first-year students. But our experience can broaden the understanding of diagnostic possibilities and ways of developing reactive and proactive coping.

\section{References}

Aspinwall, L., \& Taylor, S. (1997). A stitch in time: Self-regulation and proactive coping. Psychological Bulletin, 121(3), 417-436. https://doi.org/10.1037//0033-2909.121.3.417

Bekhter, A.A. (2017a). Prognozirovanie v Rabote Psikhologa: Vozmozhnosti Diagnostiki $i$ Razvitiya: Handbook. Khabarovsk: PNU Publ. (In Russ.)

Bekhter, A.A. (2017b). Razvitie Sovladayushchego Povedeniya Spetsialistov Pomogayushchego Profilya: Handbook. Khabarovsk: PNU Publ. (In Russ.)

Bekhter, A.A. (2019). K voprosu o proaktivnosti v sovladayushchem povedenii studentov vuza. Problemy Vysshego Obrazovaniya (1), 344-347. (In Russ.)

Bekhter, A.A. (2019). Razvitie proaktivnogo sovladayushchego povedeniya pervokursnikov s pomoshch'yu refleksivnogo treninga. Metodologiya, Teoriya, Istoriya Psikhologii Lichnosti: Conference Proceedings (pp. 524-631). Moscow: Institute of Phycology of Russian Academy of Science Publ. (In Russ.)

Bekhter, A.A., \& Filatova, O.A. (2018). Subject activity in coping behaviour of the personality. Acmeology, (1), 21-26. (In Russ.)

Bekhter, A.A., \& Golovacheva, M.V. (2020). Vzaimosvyazi Stilei Proaktivnogo Sovladeyushchego Povedeniya Studentov i Obshchego Urovnya Stressa. In E.N. Tkach (Ed.), Lichnost' $v$ obrazovatel'nom prostranstve: variativnost' podkhodov $k$ soderzhaniyu $i$ tekhnologiyam psikhologo-pedagogicheskogo soprovozhdeniya (pp. 34-39). Khabarovsk: PNU Publ. (In Russ.)

Bekhter, A.A., \& Prokhorova, A.E. (2020). Osobennosti proaktivnogo sovladayushchego povedeniya studentov. In A.K. Kulieva (Ed.), Psikhologiya Sluzhebnoi Deyatel'nosti: Dostizheniya i Perspektivy. Conference Proceedings (pp. 740-741). Saint Petersburg: Skifiya-print Publ. (In Russ.)

Belinskaya, E.P., Vecherin, A., \& Agadullina, E.R. (2019). The Relationship of Proactive Coping and Severity of Symptoms of Post-Traumatic Stress Disorder. Advances in Social Science, Education and Humanities Research, (321), 10-14. http://dx.doi.org/10.2991/ispcpep-19.2019.3

Belinskaya, E.P., Vecherin, A.V., \& Agadullina, E.R. (2018). Proactive Coping Inventory: Adaptation to a Non-Clinical Sample and the Predictive Capability. Clinical Psychology and Special Education, 7(3), 192-211. https://doi.org/1017759/psyclin.2018070312 (In Russ.)

Bityutskaya, E.V, \& Korneev, A.A. (2020). Diagnostics of coping prerequisite: approbation of the Questionnaire "Types of Orientations in Difficult Situations". Psikhologicheskii Zhurnal, 41(1), 97-111. https://doi.org/10.31857/S020595920007902-8 (In Russ.)

Bolger, N., \& Zuskerman, A. (1995). A Framework for studying personality in the stress process. Journal of Personality and Social Psychology, 69(5), 890-902. 
Gagarin, A.V., \& Bekhter, A.A. (2014). Developing coping strategies in would-be psychologists by employing reflexive methods in education process. RUDN Journal of Psychology and Pedagogics, (3), 90-96. (In Russ.)

Greenglass, E., Schwarzer, R., Jakubiec, D., Fiksenbaum, L., \& Taubert, S. (1999). The Proactive Coping Inventory (PCI): A Multidimensional Research Instrument. Stress and Anxiety Research Society (STAR): Proceeding. 20th International Conference. Cracow, Poland. Retrieved February 2, 2021, from http://www.alabanza.com/lothian/york/

Karpov, A.V. (2003). Refleksivnost' kak psikhicheskoe svoistvo i metodika ee diagnostiki. Psikhologicheskii Zhurnal, 24(5), 45-57. (In Russ.)

Kornilova, T.V. (2016). Psychology of choice and decision making as cognitive and personality moderated overcoming of uncertainty. Psikhologicheskii Zhurnal, 37(3), 113-124. (In Russ.)

Korzun, S.A. (2016) Proactive and reactive coping behavior of pedagogical university. Nauchnye trudy Respublikanskogo instituta vysshei shkoly, 16(2), 100-106. (In Russ.)

Krukova, T.L., Kuftyak, E.V., \& Zamishlyaeva, M.S. (2005). Adaptation of techniques, study of coping behavior way of coping questionnaire (questionnaire of coping methods of R. Lazarus and S. Folkman). Psikhologicheskaya Diagnostika, (3), 57-76. (In Russ.)

Kuftyak, E.V. (2019). Sovladayushchee povedenie v period vzrosleniya: sootnoshenie mekhanizmov psikhologicheskikh zashchit, reaktivnogo i proaktivnogo sovladaniya. Metodologiya, Teoriya, Istoriya Psikhologii Lichnosti: Conference Proceedings (pp. 680-689). Moscow: Institute of Phycology of Russian Academy of Science publ. (In Russ.)

Kuftyak, E.V., \& Bekhter, A.A. (2020). Stress i proaktivnoe sovladayushchee povedenie v period pandemii COVID-19: dannye onlain-oprosa. Meditsinskaya Psikhologiya $v$ Rossii, 12(6). (In Russ.)

Kuftyak, E.V., Bekhter, A.A., \& Kirpan, S.A. Opyt adaptatsii metodiki otsenki studencheskogo stressa. Ekopsikhologicheskie issledovaniya - 6: Ekologiya detstva i psikhologiya ustoichivogo razvitiya. Conference Proceedings (pp. 223-227). Moscow: Psychological Institute of the Russian Academy of Education Publ.; Kursk: Universitetskaya kniga Publ. (In Russ.)

Lazarus, R.S. (1993). Coping theory and research: past, present, and future. Psychosomatic Medicine, 55, 234-247.

Leontiev, D.A., \& Rasskazova, E.I. (2006). Test Zhiznestoikosti. Moscow: Smysl Publ. (In Russ.)

Miao, M., \& Gan, Y. (2019). How does meaning in life predict proactive coping? The selfregulatory mechanism on emotion and cognition. Journal of Personality, 87(3), 579-592. https://doi.org/10.1111/jopy.12416

Schwarzer, R. (2001). Stress, resources, and proactive coping. Applied Psychology: An International Review, 50(3), 400-407.

Sekatskaya, E.O. (2020). Temporal perspective of individual as a determinant of proactive coping behavior. Nauka: Kompleksnye Problemy, (2), 19-24. (In Russ.)

Sergienko, E.A. (2009). Behavior control: individual resources of subject control. Psikhologicheskie Issledovaniya, 5(7), 1. Retrieved February 2, 2021, from http://psystudy.ru/index.php/num/2009n5-7/223-\#e3 (In Russ.)

Sircova, A., Sokolova, O.V., \& Mitina, O.V. (2008). Adaptation of F. Zimbardo Time Perspective Inventory. Psikhologicheskii Zhurnal, 29(3), 101-109. (In Russ.)

Slabinsky, V.Yu., Voishcheva, N.M., Neznanov, N.G., Nikiforov, G.S., \& Ulyanov, I.G. (2019). Psychological features of reactive, active and proactive types of coping behavior: Level approach. Psychiatry, Psychotherapy and Clinical Psychology, 10(3), 539-545. (In Russ.)

Slabisky, V.Yu., Voishcheva, N.M., Neznanov, N.G., Ulianov, I.G., \& Kharkova, O.V. (2019). Assessment of the efficiency of proactive behavior training and individual psychotherapy 
among persons with different degrees of professional burnout. Human Ecology, 10(3), 28-34. https://doi.org/10.33396 / 1728-0869-2019-11-28-34 (In Russ.)

Sleczka, P., Braun, B., Grüne, B., Bühringer, G., \& Kraus, L. (2016). Proactive coping and gambling disorder among young men. Journal of Behavioral Addictions, 5(4), 639-648. https://doi.org/10.1556/2006.5.2016.080

Starchenkova, E.S. (2009). The concept of proactive coping behaviour. Vestnik Sankt-Peterburgskogo Universiteta. Series 12: Psychology, Sociology Pedagogy, (2-1), 198-205. (In Russ.)

Starchenkova, E.S. (2012). Psychological resources of proactive coping behavior. Vestnik Sankt-Peterburgskogo Universiteta. Series 12: Psychology, Sociology Pedagogy, (1), 51-61. (In Russ.)

Straud, C.L., \& McNaughton-Cassill, M. (2019). Self-blame and stress in underground college students: The mediating role of proactive coping. Journal of American College Health, 67(4), 367-373.

Vaculikova, J. (2016). Proactive coping behavior in sample of university students in helping professions. Sociální pedagogika [Social Education], 4(2), 38-55. https://doi: 10.7441/soced.2016.04.02.03

Vaculikova J., Johnson, J., \& Flint, D. (2019). Evaluating the factor structure of the proactive and preventive coping of graduate students. Turkish Online Journal of Educational Technology. Retrieved February 2, 2021, from https://www.researchgate.net/publication/332370236

Zakharova, A.Y., \& Trusova, A.V. (2019). Time perspective in patients with affective disorders: Review of scientific research. RUDN Journal of Psychology and Pedagogics, 16(3), 435-450. http://dx.doi.org/10.22363/2313-1683-2019-16-3-435-450 (In Russ.)

\author{
Article history: \\ Received: 9 September 2020 \\ Revised: 7 February 2021 \\ Accepted: 15 February 2021
}

\title{
For citation:
}

Bekhter, A.A., Gagarin, A.V., \& Filatova, O.A. (2021). Reactive and Proactive Coping Behaviors in Russian First-Year Students: Diagnostics and Development Opportunities. RUDN Journal of Psychology and Pedagogics, 18(1), 85-103. http://dx.doi.org/10.22363/23131683-2021-18-1-85-103

\section{Bio notes:}

Anna A. Bekhter, PhD in Psychology, is Associate Professor at the Psychological Department, and Director of the Psychological Center of the Pacific National University (Khabarovsk, Russia). ORCID iD: https://orcid.org/0000-0002-1017-558X, eLIBRARY SPIN-code: 8977-2383. E-mail: behter2004@mail.ru.

Alexander V. Gagarin, $\mathrm{ScD}$ in Education, is Professor of the Psychology Faculty at the Institute for Social Sciences of the Russian Presidential Academy of National Economy and Public Administration (Moscow, Russia). ORCID iD: https://orcid.org/0000-00019287-460X, eLIBRARY SPIN-code: 2382-5587. E-mail: alexandervgagarin@gmail.com.

Olesya A. Philatova is lecturer, postgraduate student of the Psychological Department of the Pacific National University (Khabarovsk, Russia). ORCID iD: https://orcid.org/00000002-4948-3678, eLIBRARY SPIN-code: 3321-4751. E-mail: 0409800911@mail.ru. 


\title{
Реактивное и проактивное совладающее поведение у российских студентов первого года обучения: диагностика и возможности развития
}

\author{
А.А. Бехтер ${ }^{1}$, А.В. Гагарин ${ }^{2}$, О.А. Филатова ${ }^{1}$ \\ ${ }^{1}$ Тихоокеанский государственный университет, \\ Российская Федераџия; 680000, Хабаровск, ул. Карла Маркса, д. 68 \\ ${ }^{2}$ Российская академия народного хозяйства и государственной службы \\ при Президенте Российской Федерации, \\ Российская Федерачия, 119571, Москва, пр-кт Вернадского, д. 82
}

\begin{abstract}
Аннотация. Актуальность исследования определена ролью процессов адаптации первокурсников к университетской среде, которая является важнейшим (предварительным) этапом для: а) успешного преодоления различного рода трудностей в обучении; б) комфортного и конструктивного взаимодействия с преподавателями и другими студентами; в) поиска и применения стратегии адаптивного поведения в связи с новыми условиями жизни. Развитие проактивного совладания является ключевым фактором эффективной учебной деятельности студентов, представляя собой «платформу» для личностного роста. Цель исследования - определение возможностей диагностики и развития реактивного и проактивного совладающего поведения у студентов первого года обучения. В исследовании приняли участие 272 студента первого курса Тихоокеанского государственного университета (136 студентов экспериментальной группы, которые обратились за помощью в Психологический центр университета в 2019 году и 136 студентов-добровольцев первого курса в качестве контрольной группы). Для диагностики использованы методика Proactive Coping Inventory (PCI) в адаптации Е.П. Белинской и др., опросник копинг-стратегий Р. Лазаруса в адаптации Т.Л. Крюковой и др., тест жизнестойкости С. Мадди (в адаптации Д.А. Леонтьева и Е.И. Рассказовой), опросник временной перспективы Ф. Зимбардо (в адаптации А. Сырцовой и др.), методика рефлексивности А.В. Карпова. В результате у первокурсников выявлены невысокие уровни развития реактивного и проактивного совладания; высокие уровни социальной и эмоциональной поддержки, бегства-избегания; средние уровни стратегического планирования и поиска информационной поддержки; сниженный уровень рефлексивного, прогностического ресурса. Показано, что поиск социальной, эмоциональной и информационной поддержки является базой для построения стратегий адаптивного поведения. Подтверждено, что самоконтроль и категория будущего являются модерирующими для всех видов проактивного совладания. На основе кластерного анализа были выделены три типа отличающихся уровнями и содержанием реактивного и проактивного поведения (неадаптивный, реактивный, активный с тенденцией к проактивному). Повторные измерения показали, что индивидуальные и групповые формы психологической интервенции вызывают изменения в показателях реактивно-проактивного совладающего поведения, что может расцениваться как положительная динамика развития поведения студентов экспериментальной группы. В заключении сформулирован вывод о возможностях использования разных форм психологической поддержки (индивидуального консультирования, тренингов и групп самопомощи) в оптимизации проактивного совладающего поведения первокурсников.
\end{abstract}

Ключевые слова: проактивное совладающее поведение, реактивное совладающее поведение, личностные ресурсы, студенты первого года обучения, психологическая помощь, тренинг 


\section{История статьи:}

Поступила в редакцию: 17 сентября 2020 г.

Принята к печати: 15 февраля 2021 г.

\section{Для цитирования:}

Bekhter A.A., Gagarin A.V., Filatova O.A. Reactive and proactive coping behaviors in Russian first-year students: diagnostics and development opportunities // Вестник Российского университета дружбы народов. Серия: Психология и педагогика. 2021. T. 18. № 1. C. 85-103. http://dx.doi.org/10.22363/2313-1683-2021-18-1-85-103

\section{Сведения об авторах:}

Бехтер Анна Александровна, кандидат психологических наук, доцент, доцент кафедры психологии, директор Психологического центра Тихоокеанского государственного университета (Хабаровск; Россия). ORCID iD: https://orcid.org/0000-00021017-558X, eLIBRARY SPIN-код: 8977-2383. E-mail: behter2004@mail.ru.

Гагарин Александр Валерьевич, доктор педагогических наук, профессор факультета психологии Института общественных наук Российской академии народного хозяйства и государственной службы при Президенте Российской Федерации (Москва; Россия). ORCID iD: https://orcid.org/0000-0001-9287-460X, eLIBRARY SPIN-код: 2382-5587. E-mail: alexandervgagarin@gmail.com.

Филатова Олеся Анатольевна, аспирант и преподаватель кафедры психологии Тихоокеанского государственного университета (г. Хабаровск, Россия). ORCID iD: https://orcid.org/0000-0002-4948-3678, eLIBRARY SPIN-код: 3321-4751. E-mail: 0409800911@mail.ru. 